\title{
Job Satisfaction among Employees in the Government Sector: A case of Ministry of Manpower Inspectors
}

\author{
Talal Al Rawahi \\ MBA Student, Faculty of Business, Sohar University, Sultanate of Oman \\ Email: talalalrawahi.tm@gmail.com
}

Article History: Received on $12^{\text {st }}$ Mar. 2020, Revised on $19^{\text {th }}$ Apr. 2020, Published on $6^{\text {th }}$ July 2020

\begin{abstract}
Purpose of the study: The objective of the research is to examine the relationship between the factors nature of the job, working condition, motivation, career growth and job satisfaction of labour inspectors in the Ministry of manpower in the Sultanate of Oman.

Design/Methodology: The study includes all the inspectors working in the different Human Resources Department branches of the ministry of manpower in Oman. 147 respondents from all the 269 inspectors working in the ministry were selected and the data was collected using a questionnaire. Statistical Package for Social Sciences (SPSS) was used to analyse the data. Non-probability sampling technique was used for sample selection based on their job position, knowledge and the effective relationship of the inspectors.

Findings: The result of the research was that there was a statistically significant relationship between the nature of work and job satisfaction; the significant relationship between working conditions and job satisfaction and significant relationship between career growth and job satisfaction. But there was no statistically significant relationship between motivations and job satisfaction.

It was also observed that the Ministry of Manpower fully insures the risks of these jobs. Further, increased attention is being paid to the working condition needs of inspectors, including rental cars and clothing appropriate to the sites, providing incentives, free scholarships and training inside and outside the country to ensure inspectors are satisfied with their work.
\end{abstract}

Research Implications: This research reinforces the theoretical framework of the importance of job satisfaction between work and inspectors of the Ministry of Manpower through studying the dependent variables that affect the level of job performance to enable inspectors to increase their efficiency and productivity of work.

Practical Implications: Through this research, job satisfaction has been identified with the labour inspectors at the Ministry of Manpower, and the proposals that have been made that serve the Ministry of Manpower in improving the level of job satisfaction through taking study recommendations.

Originality: There was no study was conducted before in the sultanate of Oman in relates to satisfaction of Labour Inspectors.

Keywords: Job satisfaction, Labour Inspectors, Ministry of Manpower, Ministry of Labour, Working Conditions, Motivation, Career Growth.

\section{Introduction}

For any business organisations to achieve their goals, they must be very much concerned with human factors. Neglecting human resources, especially in the government sector, leads to a decrease in the performance of the employees. Human resources are among the most important factors driving the most valuable and unique assets of the organization. The success of the management of an organization is to manage human resources - a real, exciting and challenging task since the world is a global village and economies keep constantly changing (Betts, 2020). Managers across the public, private and not-for-profit sectors are increasingly realizing that the employees are the most important assets of their organization and important source as competitive advantage comes from having the best systems in place to attract, motivate and manage the human resources of their organization (Mesch, 2010). 
Human resources contribute to the performance and achievement of the goals of any organization, as humans are the main element. Human resources play a major role in economic development, as it is the main wealth of countries, and without them, the other factors like productivity, effectiveness, and client satisfaction will not have any value. Human resources of an organisation are important to create competitive advantage and value in the world market, as essential for development (Coomber \& Barribal, 2007). Any organisation should provide a good working environment, support, and allow workers to develop their potential and motivate them to stay in the organisation. Natural and financial resources, despite their importance, come at a later level compared to human resources. Without the human element, there can be no real development in the foundation, and therefore human development is a necessity and of utmost importance. Therefore, countries put human resources development as a top priority during the planning process, because they know very well that human development is the one that accelerates the comprehensive development process in all fields. Therefore, it becomes necessary to improve job satisfaction. Making employers' satisfaction is not only a strong determinant of increasing individual capability, but it enhances the performance of the entire organisation.

Job satisfaction could be defined as the positive attitude of an employee at the workplace. Job satisfaction will be described as the number of overall positive impact or feelings that people have towards their duties (Fieldman and Arnold, 1983). The extent of contentedness an employee could experience with the nature of the job and the working environment. Job satisfaction is an important criterion which goes with performance, productivity, and effectiveness related to work and is the most important goal of companies. Job satisfaction is a major factor in any organisation to drive its employees to achieve efficient results. The term job satisfaction expresses the positive feeling felt by the employee in general towards his/her work, due to the fulfilment of his needs and his desires in the work, as it is one of the basic goals that most institutions seek to obtain because of its role in increasing the productivity of workers and motivating them. Motivation is a key factor that leads to job satisfaction. Motivation is the best way to satisfy its employees which results in better performance and outstanding yield which in turn leads to increased productivity in the organisation. Job satisfaction plays a critical role when it comes to the effectiveness and efficiency of the business. It is the employees in the organisation who are considered as the best assets and ladder to success. When an organisation regards its employees and keeps them satisfied it stays in the market for long without any conflict.

Existence of labour law and monitoring the compliance with the labour law and its application by companies will build the labour force stronger. Therefore, labour inspection is one of the core functions of a labour administration system and has been the subject to international standards - set by International Labour Organization (ILO), with references to the Treaty of Versailles and the ILO Constitution. In addition to these constitutional documents, the ILO has adopted numerous instruments over the years dealing with the structure and functioning of the system of labour inspection, either exclusively or as an important element for prevention and labour law compliance (ILO, 2011).

As per the Ministry of Manpower, Sultanate of Oman, the labour inspection is one of the responsibilities of Manpower, monitoring the implementation of establishments, the provisions of the Labour Law and the regulations and decisions implementing it ( $\underline{\mathrm{ILO}, 2008)}$. Labour inspection is the procedures, controls and preventive measures, the ministry of labour ensures for the effective implementation of the provisions of the labour law and other regulations and decisions related to work and workers. It aims at improving the work environment and establishing cooperation between the parties to work and directing them to the best ways to follow to improve work conditions. It takes legal measures towards violators from employers or workers whenever the need arises.

Ministry of manpower aims at monitoring and follow-up of the implementation of legislation and decisions issued by the organisation for the labour market, verifying the application of private-sector establishments as per the Omani labour law. The concern gets raising awareness, for business owners or workers to familiarise them with the importance of the principles, rights, and foundations legally established by them. The ministry also concerned with the following up of complaints and reports that may affect work relations between workers and employers as its specialists seek to find appropriate solutions to settle disputes ensuring stable labour relations. At the same time, the satisfaction level of inspectors at their work is important which is dependent on various factors. Ministry of manpower exercises the application of the labour law through several departments with different specialities, and labour inspectors perform most of these actions (ILO, $\underline{2008)}$. 
The departments in which labour inspectors work are as follows:

i. Joint inspection team - specialised in following up non-Omani workers working in the country illegally. ii. The Inspection Department -plays a pivotal role in monitoring the compliance of the labour law by the private sector institutions.

iii. Occupational Health and Safety Department -following up the establishments operating in the private sector complying with the regulations for occupational health and safety.

iv. Labour Dispute Settlement Department - complaints of the individuals and collective worker cases submitted by businessmen and workers in private sector institutions are pursued.

v. Labour Services Department - provides services to workers in private establishments to preserve their rights and to encourage them to increase production and commitment in their work through awareness.

vi. The Union Syndicates Department -responsible for the system of forming, operating and registering trade unions in the Sultanate of Oman.

Since we are emphasising the importance of Job satisfaction in Government sectors, human development is the key to satisfy the employees. By laying a strong foundation, Government sectors can be more functional and productive and thus perform a vital role in the development of the Country. The world has realised the critical importance of human resource development and the economic plans aim mainly at diversifying its income sources and assured that this can only be achieved by relying on improving human resources.

The Sultanate was not far from catching up with the world, through attention to human development and investment in human development in a manner commensurate with the capabilities and conditions available to them.

\section{Background of the study}

Job satisfaction of Inspectors is very important to the ministry of manpower to keep them contribute more. Recently, inspectors have expressed dissatisfaction over their jobs because of the nature of the jobs, inadequate bonus, and overtime hours, working as an inspector in the Ministry. The salary was not incommensurate with the duties and responsibilities of his position. Some were unable to be released from their duties even after their working hours with no compensation whatsoever. A troubled relationship with the hiring managers also creating dissatisfaction of jobs. Moreover, the inspectors were required to constantly attend the court and they felt this might affect the inspectors' social relations. Further, the allowance provided by the ministry seems to be very low. The inspectors were of less hope about their future career growth. Azeem (2010) studied the relationship between aspects of the job satisfaction and demographic factors - age and job position, with organizational commitment among inspectors working in the industry sector of the Sultanate of Oman, found the similar things. The decision-makers in the ministry of manpower have the responsibility to provide them with several facilities to reduce dissatisfaction and to ensure whether the inspectors are satisfied or not. The problems faced by the inspectors - nature of the job, working condition, motivation, and career growth, therefore need to be studied to find out the reasons therefor.

\section{Research Questions}

The study will undertake the factors that affect the inspector's level of job satisfaction. The study will see if satisfied inspectors are effect by the nature of the job, working condition, motivation, and career growth.

Therefore, the research aims to study the factors affecting the inspectors' job satisfaction in the ministry of manpower and finding the relationship between these factors and job satisfaction. The study focuses on finding the answers to the following questions:

1. What is the relationship between the nature of the job to the inspectors of the ministry of manpower and job satisfaction?

2. What is the relationship between working conditions to the inspectors of the ministry of manpower and job satisfaction?

3. What is the relationship between motivation to the inspectors of the ministry of manpower and job satisfaction?

4. What is the relationship between career growth to the inspectors of the ministry of manpower and job satisfaction? 


\section{Research Objectives}

On the above lines, the objective of the research is to examine the relationship between the factors - nature of the job, working condition, motivation, career growth and job satisfaction of inspectors in the Ministry of manpower.

\section{Review of Literature}

Job satisfaction is the favourableness or unfavourableness with which the employees view their work and is the collection of positive or bad feelings with which employees view their job (Newstrom and Davis, 1997). Job satisfaction is a pleasurable or positive emotional status appearing from the assessment of one's job or job experience (Locke, 1970). Greater the employee's job satisfaction, the greater success of the organisation (Harter, Schmidt, and Hayes, 2002).

Job satisfaction is related to incentives based on individual or small groups performance, while organisational commitment is more strongly related to company-level incentives. (Drago, Estrin, Wooden, 1993). Supervision, pay, overall job satisfaction, age, and job tenure were the significant predictors of organisational commitment ( $\underline{\text { Azeem }}, 2010)$. The moderate levels of job satisfaction are based on gender and there were differences in the areas of emotional healing, promotion, and the nature of the work - the lower grades ( $\underline{\mathrm{Al}-}$ Mahdy, Al-Harthi, \& Salah El-Din, 2016). The middle-level management employees in semi-government organisations were primarily driven by an internal locus of control and most of the employees in the sector scored low in the job satisfaction scale (Hans, Mubeen, \& Ghabshi, 2013). Workers who report dissatisfaction with their jobs are statistically more likely to quit than those with higher levels of satisfaction. The cross-sectional distribution of job satisfaction responses thus contains information that enables us to predict workers' future behaviour (Clark, Georgellis \& Sanfey, 1998). Factors related to productivity, employee motivation, and relationship with colleagues and workers impact job satisfaction (Troesch and Bauer, 2017).

The process of understanding human motivation towards job satisfaction is by identifying three types of basic needs viz. the need for achievement, the need for Affiliation and the need for power (McClelland, 1965). Higher-level needs, such as self-esteem and self-fulfilment, can only be met after lower-level needs are met. (Maslow, Stephens and Heil, 1998). The motivation towards work is a factor that affects an employee's emotional commitment to the organization. (Saragih, Luturlean, \& Hadiyanto, 2020). Motivation is vital for organisations to work and without motivation, employees will not put up their best and the businesses performance would be tiny adequate (Nchorbuno, 2011). Motivation relates to the complexity of units that causes a person at work to raise his passion and enthusiasm to use his abilities to perform to accomplish organisational goals (Badawi et al., 2019; Ekundayo and Ajanaku, 2018). Factors other than finance such as Job security, good working conditions, good working relation with co-workers and employers, assistance in decision making, training motivate workers to perform well (Florence, 2014). Motivation drives a person with a direction needed to engage with the environment in an adaptive, open-ended, and problem-solving sort of an action (Reeve, 2014). General competencies use a mediating influence on the relationship between career success satisfaction and job performance (Valaei and Nikhashemi, 2017).

Career satisfaction as individuals' evaluations of their careers is often seen as one prime indicator of subjective career success (Abele, Spurk and Volmer, 2011; Ng et al., 2005). The job satisfaction was measured as the evaluation of a person's progression toward meeting different career-related goals such as income, advancement, development, and overall career goals (Hofmans, Dries, and Pepermans, 2008). Career satisfaction means satisfaction with the rate of progress and career responsibility is to measure an individual's responsibility towards their jobs, profession, and careers (Seibert and Kraimer, 2001). Largest people aim for job success, which is related to many different forms of career-related behaviour and wellbeing like proactivity, mentoring, networking, organisational learning climate, self-management, mobility, positive affectivity, and life satisfaction (Abele, Spurk and Volmer, 2011). The factors such as workrecognition, benefits, the nature of the organization, work, etc., that have an impact on employee satisfaction (Pauceanu, Hisam, \& Sanyal, 2016). Gender, age, education, and duration of the job mix the level of job satisfaction and factors such as extroversion, openness, harmony and conscience of employees affect job satisfaction positively except for neuroticism negatively (Al Shuhoomi and Khan, 2019).

Working conditions based on various factors (external factors - climate and workplaces, subjective factors gender, age, fatigue, monotonous, and other organisation related factors - shifts, speed and stress) can influence the level of performance and satisfaction of an employee (Alegre, Machuca, \& Mirabent, 2016). The environmental conditions of work such as air-conditioning, lighting, heat humidity, and noise influence the degree of individual acceptance of the work environment, that serious environmental conditions drive to 
the satisfaction of individuals with the work environment (Arafa, Nazel, Ibrahim, and Attia, 2003). Difficult working conditions limit the chances of working effectively in the profession (Billingsley, Bettini, Mathews, \& McLeskey, 2020). Useful for strategies to improve working conditions are necessitated in global supply chains (Short, Toffel and Hugill, 2019). Increasing satisfaction split into a two-step process which includes first eliminating the hygiene factors, then on the motivators to make people happy at their jobs (Small, 1971).

Job feedback - the extent to which work activities are taken out provides direct and clear information to the employee concerning how well the job is being done (Brett, Uhl-Bien, Huang, and Carsten, 2016).

Dissatisfaction with routine, has lead Declined output, low absenteeism, works turnover, and work errors, to try finding other jobs (Al-Salem, 2005)

\section{Hypotheses}

From the above review of literature, the following hypotheses were derived:

1. There are statistically significant relationships between the nature of the job the inspectors and job satisfaction

2. There are statistically significant relationships between working condition with the inspectors and job satisfaction

3. There are statistically significant relationships between motivation with the inspectors and job satisfaction

4. There are statistically significant relationships between career growths with inspectors' job satisfaction.

\section{Research Methodology}

The study includes all the inspectors working in the different Human Resources Department branches of the ministry of manpower in Oman. They were about 269 inspectors 147 respondents from all the 269 inspectors working in the ministry were selected to get information using a questionnaire. It includes job satisfaction as the dependent variable and another four independent variables which focus on working condition, nature of job, motivation and growth career. The study uses the Statistical Package for Social Sciences (SPSS) for analyzing data. Non-probability sampling technique was used for sample selection based on their job position, knowledge and the effective relationship of the inspectors. The questionnaire consisted of two sections - demographic and job satisfaction, motivation nature of work and working conditions and career growth using the Likert scale.

\section{Findings}

Table 1. Demographic information

\begin{tabular}{|l|l|c|c|}
\hline \multirow{4}{*}{ Gender } & & Frequency & Per cent \\
\hline \multirow{5}{*}{ Age } & Male & 123 & 84 \\
\cline { 2 - 4 } & Female & 24 & 16 \\
\hline \multirow{5}{*}{ Education } & Less than 25 & 0 & 0 \\
\cline { 2 - 4 } & $26-35$ & 78 & 53 \\
\cline { 2 - 4 } & $36-45$ & 64 & 44 \\
\cline { 2 - 4 } & More than 46 & 5 & 3 \\
\hline \multirow{5}{*}{ Experience } & Class 12 & 4 & 3 \\
\cline { 2 - 4 } & Diploma & 33 & 22 \\
\cline { 2 - 4 } & Bachelor & 95 & 65 \\
\cline { 2 - 4 } & Masters and above & 15 & 10 \\
\hline & Less than 5 years & 8 & 5 \\
\cline { 2 - 4 } & 6-10 years & 81 & 55 \\
\cline { 2 - 4 } & $11-15$ years & 45 & 31 \\
\cline { 2 - 4 } & More than 16 years & 13 & 9 \\
\hline & Inpection & 102 & 69.4 \\
\cline { 2 - 4 } & Legal viewer & 14 & 9.5 \\
\cline { 2 - 4 } & Asst manager / HR section & 20 & 13.6 \\
\cline { 2 - 4 } & Manager and above & 11 & 7.5 \\
\hline \multirow{3}{*}{ Department } & Joint inspection team & 52 & 35.6 \\
\cline { 2 - 4 } & Inspection Dept. & & \\
\hline
\end{tabular}


https://doi.org/10.47259/ijrebs.113

\begin{tabular}{|l|l|c|c|}
\hline \multirow{5}{*}{} & Safety and Health Dept. & 5 & 3.4 \\
\cline { 2 - 4 } & other Dept. & 20 & 13.6 \\
\hline \multirow{5}{*}{ Location } & Muscat & 65 & 44.2 \\
\cline { 2 - 4 } & Dhofar & 7 & 4.8 \\
\cline { 2 - 4 } & Albatnah North & 19 & 12.9 \\
\cline { 2 - 4 } & Al batinah South & 6 & 4.1 \\
\cline { 2 - 4 } & Al dhaklia & 10 & 6.8 \\
\cline { 2 - 4 } & Al sharqia North & 12 & 8.2 \\
\cline { 2 - 4 } & Al sharqia South & 5 & 3.4 \\
\cline { 2 - 4 } & Al wusta & 3 & 2.0 \\
\cline { 2 - 4 } & Aldhahirah & 12 & 8.2 \\
\cline { 2 - 4 } & Alburaimi & 5 & 3.4 \\
\cline { 2 - 4 } & Musandam & 3 & 2.0 \\
\hline
\end{tabular}

Source: Survey

Table.2 Test of Normality

\begin{tabular}{|c|c|c|c|c|c|c|}
\hline & Kolm & rov-Smir & & & iro-Wilk & \\
\hline & Statistic & $\mathrm{df}$ & Sig. & Statistic & $\mathrm{df}$ & Sig. \\
\hline js1 & .241 & 147 & .000 & .889 & 147 & .000 \\
\hline js2 & .196 & 147 & .000 & .889 & 147 & .000 \\
\hline js3 & .171 & 147 & .000 & .886 & 147 & .000 \\
\hline js4 & .293 & 147 & .000 & .807 & 147 & .000 \\
\hline js5 & .184 & 147 & .000 & .908 & 147 & .000 \\
\hline js6 & .197 & 147 & .000 & .891 & 147 & .000 \\
\hline js7 & .245 & 147 & .000 & .831 & 147 & .000 \\
\hline js8 & .145 & 147 & .000 & .910 & 147 & .000 \\
\hline js9 & .234 & 147 & .000 & .884 & 147 & .000 \\
\hline $\mathrm{m} 1$ & .243 & 147 & .000 & .853 & 147 & .000 \\
\hline $\mathrm{m} 2$ & .277 & 147 & .000 & .824 & 147 & .000 \\
\hline $\mathrm{m} 3$ & .261 & 147 & .000 & .821 & 147 & .000 \\
\hline $\mathrm{m} 4$ & .362 & 147 & .000 & .647 & 147 & .000 \\
\hline $\mathrm{m} 5$ & .244 & 147 & .000 & .815 & 147 & .000 \\
\hline $\mathrm{m} 6$ & .376 & 147 & .000 & .626 & 147 & .000 \\
\hline $\mathrm{m} 7$ & .289 & 147 & .000 & .730 & 147 & .000 \\
\hline $\mathrm{m} 8$ & .324 & 147 & .000 & .718 & 147 & .000 \\
\hline $\mathrm{m} 9$ & .241 & 147 & .000 & .801 & 147 & .000 \\
\hline $\mathrm{n} 1$ & .162 & 147 & .000 & .908 & 147 & .000 \\
\hline $\mathrm{n} 2$ & .186 & 147 & .000 & .900 & 147 & .000 \\
\hline $\mathrm{n} 3$ & .342 & 147 & .000 & .744 & 147 & .000 \\
\hline $\mathrm{n} 4$ & .320 & 147 & .000 & .812 & 147 & .000 \\
\hline n5 & .255 & 147 & .000 & .835 & 147 & .000 \\
\hline n6 & .250 & 147 & .000 & .796 & 147 & .000 \\
\hline $\mathrm{n} 7$ & .328 & 147 & .000 & .704 & 147 & .000 \\
\hline $\mathrm{c} 1$ & .173 & 147 & .000 & .891 & 147 & .000 \\
\hline c2 & .221 & 147 & .000 & .899 & 147 & .000 \\
\hline c3 & .268 & 147 & .000 & .862 & 147 & .000 \\
\hline $\mathrm{c} 4$ & .148 & 147 & .000 & .900 & 147 & .000 \\
\hline $\mathrm{c} 5$ & .244 & 147 & .000 & .883 & 147 & .000 \\
\hline c6 & .176 & 147 & .000 & .909 & 147 & .000 \\
\hline c7 & .222 & 147 & .000 & .886 & 147 & .000 \\
\hline c8 & .282 & 147 & .000 & .833 & 147 & .000 \\
\hline $\mathrm{f1}$ & .166 & 147 & .000 & .907 & 147 & .000 \\
\hline $\mathrm{f} 2$ & .190 & 147 & .000 & .911 & 147 & .000 \\
\hline f3 & .193 & 147 & .000 & .897 & 147 & .000 \\
\hline
\end{tabular}

Source: Survey 
Table.3 Reliability Test coefficients

\begin{tabular}{|c|c|}
\hline Alpha coefficient & Job satisfaction \\
\hline 0.945 & Stability coefficient all scale (36) items \\
\hline 0.879 & The first axis of job satisfaction (9) paragraphs \\
\hline 0.720 & The second axis Motivation (9) paragraphs \\
\hline 0.829 & The third axis the Nature of job (7) paragraphs \\
\hline 0.911 & The fourth axis the Condition of job (8) paragraphs \\
\hline 0.316 & The fifth axis Future career (3) paragraphs \\
\hline
\end{tabular}

Source: survey

The reliability coefficient Cronbach-Alpha estimated to be 0.945 , which shows a good level of internal consistency. Table. 3 explains the reliability values of all variables were more than 0.6 which indicate that the research questions were strong and reliable. It can be seen that the value of Cronbach Alpha of motivation and working condition were high 0.720, 0.829 and 0.911 while Career growth has the lowest Cronbach Alpha score of 0.316 , maybe because of three items for the construct of growth career in the questionnaire.

Table.4 Mean and standard deviation of data of job satisfaction among inspectors in the Ministry of Manpower

\begin{tabular}{|l|c|c|c|c|c|}
\hline & $\mathrm{N}$ & Minimum & Maximum & Mean & $\begin{array}{c}\text { Standard } \\
\text { Deviation }\end{array}$ \\
\hline Job Satisfaction & 147 & 1 & 5 & 2.59 & 1.204 \\
\hline Motivation & 147 & 1 & 5 & 2.26 & 1.188 \\
\hline Nature of job & 147 & 1 & 5 & 3.06 & 1.273 \\
\hline Working Condition & 147 & 1 & 5 & 2.50 & 1.178 \\
\hline Career Growth & 147 & 1 & 5 & 3.05 & 1.281 \\
\hline
\end{tabular}

Source: Survey

Table. 4 explains the centrally placed values of all the variables used in this research for the job satisfaction of the inspectors. The mean value for the nature of the job is the highest (3.06). All the other variables and variability among these scores (the standard deviation) is also low showing the less dispersion in data. Motivation has the lowest mean value 2.26 with a standard deviation of 1.188 . On the other hand, career growth has the highest standard deviation value of 1.281, with mean 3.05.

Table.5 Correlation Analysis of job satisfaction among inspectors in the Ministry of Manpower

\begin{tabular}{|c|c|c|c|c|c|c|}
\hline & & $\begin{array}{c}\text { job } \\
\text { satisfactio } \\
n\end{array}$ & Motivation & $\begin{array}{l}\text { Nature of } \\
\text { job }\end{array}$ & $\begin{array}{l}\text { Growth } \\
\text { career }\end{array}$ & $\begin{array}{l}\text { Working } \\
\text { condition }\end{array}$ \\
\hline \multirow[t]{3}{*}{ job satisfaction } & Pearson Correlation & 1 & $.444^{* *}$ & $.549^{* *}$ & $.476^{* *}$ & $.579^{* *}$ \\
\hline & Sig. (2-tailed) & & .000 & .000 & .000 & .000 \\
\hline & $\mathrm{N}$ & 147 & 147 & 147 & 147 & 147 \\
\hline \multirow[t]{3}{*}{ Motivation } & Pearson Correlation & $.444^{\text {** }}$ & 1 & $.424^{* *}$ & $.356^{* *}$ & $.553^{* *}$ \\
\hline & Sig. (2-tailed) & .000 & & .000 & .000 & .000 \\
\hline & $\mathrm{N}$ & 147 & 147 & 147 & 147 & 147 \\
\hline \multirow[t]{3}{*}{ Nature of job } & Pearson Correlation & $.549^{* *}$ & $.424^{* *}$ & 1 & $.491^{* *}$ & $.422^{* *}$ \\
\hline & Sig. (2-tailed) & .000 & .000 & & .000 & .000 \\
\hline & $\mathrm{N}$ & 147 & 147 & 147 & 147 & 147 \\
\hline \multirow[t]{4}{*}{ Growth career } & Pearson Correlation & $.476^{* *}$ & $.356^{* *}$ & $.491^{* *}$ & 1 & $.367^{* *}$ \\
\hline & Sig. (2-tailed) & .000 & .000 & .000 & & .000 \\
\hline & $\mathrm{N}$ & 147 & 147 & 147 & 147 & 147 \\
\hline & Pearson Correlation & $.579^{* *}$ & $.553^{* *}$ & $.422^{* *}$ & $.367^{* *}$ & 1 \\
\hline
\end{tabular}




\begin{tabular}{|l|l|r|r|r|r|r|}
\hline \multirow{2}{*}{$\begin{array}{l}\text { Working } \\
\text { condition }\end{array}$} & Sig. (2-tailed) & .000 & .000 & .000 & .000 & 147 \\
\cline { 2 - 7 } & $\mathrm{N}$ & 147 & 147 & 147 & 147 & 147 (2-tailed). \\
**. Correlation is significant at the 0.01 level (2) \\
|
\end{tabular}

Source: Survey

The correlation coefficient between the motivation and job satisfaction is 0.444 , meaning the motivation is causing $44 \%$ variation in inspectors' job satisfaction. Its mean if the motivation factor of inspectors among the ministry of manpower increased by $100 \%$ the level of satisfaction will rise only $44 \%$ that is not very high but is acceptable.

The correlation coefficient between the nature of job and job satisfaction is 0.549 , meaning that the nature of the job is causing 55\% variation in inspectors' job satisfaction. It means that if the nature of the job factor of inspectors among the ministry of manpower increased by $100 \%$ the level of satisfaction will rise only $55 \%$ that is not very high but it is at a better level.

The correlation coefficient between Career Growth and Job satisfaction is 0.476, it means the Growth career is affecting $48 \%$ variations in the inspectors' job satisfaction. It means that if the Career Growth factor of inspectors among the ministry of manpower increased by $100 \%$ the level of satisfaction will increase only $48 \%$ that is not very high but is acceptable.

The correlation coefficient between the Working condition and job satisfaction is 0.579 , meaning that the Working condition is causing 58\% variation in inspectors' job satisfaction. It means that if the Working condition factor of inspectors among the ministry of manpower increased by $100 \%$, the level of satisfaction will raise only $58 \%$ that is not so high but at a better level.

\section{Regression Analysis}

Table.6 (a) Linear regression of job satisfaction among inspectors in the Ministry of Manpower

\begin{tabular}{|l|c|c|c|c|c|}
\hline \multicolumn{6}{|c|}{ Model Summary b } \\
\hline Model & $\mathrm{R}$ & $\mathrm{R}$ Square & $\begin{array}{c}\text { Adjusted R } \\
\text { Square }\end{array}$ & $\begin{array}{c}\text { Std. Error of the } \\
\text { Estimate }\end{array}$ & Durbin-Watson \\
\hline 1 & $.694^{\mathrm{a}}$ & .482 & .467 & .883 & 1.661 \\
\hline${ }^{\text {aPredictors: (Constant) motivation, nature of job, working condition and career growth }}$ \\
\hline \\
'bependent Variable: Job satisfaction \\
Source: Survey
\end{tabular}

Table.6 (a) explains multiple correlation coefficient $(\mathrm{R})$ and correlation dependent variable explain (R square). The R-value is 0.694 and $\mathrm{R}$ Square is 0.482 very low, so according to the value of $\mathrm{R}$ Square value, it is noted that all the independent variables (motivation, nature of job, working condition and career growth) affected the dependent variable (job satisfaction) by $48 \%$ ). And the standard of Durbin Watson is near to 2 , as the result of this test is 1.661 .

Table.6 (b) ANOVA ${ }^{\mathrm{a}}$

\begin{tabular}{|l|l|r|r|r|r|r|}
\hline \multicolumn{2}{|c|}{ Model } & $\begin{array}{c}\text { Sum of } \\
\text { Squares }\end{array}$ & df & $\begin{array}{c}\text { Mean } \\
\text { Square }\end{array}$ & F & Sig. \\
\hline \multirow{2}{*}{1} & Regression & 103.061 & 4 & 25.765 & 32.331 & $.000^{\mathrm{b}}$ \\
\cline { 2 - 8 } & Residual & 110.789 & 142 & .780 & & \\
\cline { 2 - 7 } & Total & 213.850 & 146 & & & \\
\hline
\end{tabular}

Sources: Survey

The ANOVA test measures the significance levels of research. Table.6(b) sum of square of regression represents the overall experimental effects (level of satisfaction among the inspectors. the p-value is 0.000 , meaning that there is a significant impact between the variables. So we can say that there is strong impact of motivation, nature of the job, working condition and growth career on job satisfaction. Value of $F$ is 32.331 , which gives significance with a p-value of .000 (less than the .05 in alpha levels) which means there are 
statistically significant differences between the means of different levels of the job satisfaction variable. So it is a good fit for the data.

Table.6 (c) Coefficients ${ }^{\mathrm{a}}$

\begin{tabular}{|c|c|c|c|c|c|c|c|c|}
\hline & \multirow[t]{2}{*}{ Model } & \multicolumn{2}{|c|}{$\begin{array}{c}\text { Unstandardized } \\
\text { Coefficients }\end{array}$} & \multirow{2}{*}{$\begin{array}{c}\text { Standardised } \\
\text { Coefficients } \\
\text { Beta } \\
\end{array}$} & \multirow[t]{2}{*}{$\mathrm{t}$} & \multirow[t]{2}{*}{ Sig. } & \multicolumn{2}{|c|}{$\begin{array}{l}\text { Collinearity } \\
\text { Statistics }\end{array}$} \\
\hline & & $\mathrm{B}$ & Std. Error & & & & Tolerance & VIF \\
\hline \multirow[t]{5}{*}{1} & (Constant) & .750 & .281 & & 2.665 & .009 & & \\
\hline & Motivation & .061 & .077 & .061 & .800 & .425 & .637 & 1.569 \\
\hline & Nature of job & .265 & .070 & .281 & 3.774 & .000 & .659 & 1.517 \\
\hline & \begin{tabular}{|l} 
Working \\
condtion
\end{tabular} & .190 & .073 & .185 & 2.582 & .011 & .714 & 1.401 \\
\hline & \begin{tabular}{|l|} 
Career \\
Growth
\end{tabular} & .337 & .071 & .360 & 4.730 & .000 & .631 & 1.586 \\
\hline
\end{tabular}

According to the Table.6(c), the significant value of Coefficients regression which measure the relations between dependent and independent variables in the research VIF less than 10 so its standard and the Tolerance more than 0.2 , so it is also standard.

There is a statistically significant relationship between the nature of the job of the inspectors and job satisfaction. The Coefficient beta for the independent variable relationship with nature of the job $r$ is 0.070 and the significant value is 0.000 which mean that $\mathrm{p}$-value is less than 0.05 . So there is a statistically significant relationship between the nature of the job and job satisfaction (Alegre, Machuca, \& Mirabent, 2016). From this result Hypothesis, 1 is accepted. The researcher believes that the degree of the nature of the work of the inspectors is high due to work challenges, and the inspectors use different skills, capabilities and experiences and allocate their studies according to the nature of their work.

There is a statistically significant relationship between working condition with inspectors and job satisfaction. Coefficient beta for the independent variable relationship with the working condition is 0.185 and the significant value is 0.011 which mean that $\mathrm{p}$-value is less than 0.05 . So there is a statistically significant relationship between relationship working condition and job satisfaction. From this result Hypothesis, 2 is accepted. The researcher believes that the degree of working conditions of the inspectors is high due to The capabilities provided by the ministry are good, most tasks are clear, and most inspectors have full knowledge of their work tasks (Alegre, Machuca, \& Mirabent, 2016).

The Coefficient beta for the independent variable motivation is 0.061 and the significant value is 0.425 , that means the $\mathrm{p}$-value is more than 0.05 . The result indicates that there is no statistically significant relationship between motivation and job satisfaction. This result does not support the hypothesis 3 and therefore hypothesis 3 is rejected.

The researcher believes that the inspectors' motivation level is low due to their dissatisfaction with the inspection allowance, which reflects negatively on their desire to work.

There is a statistically significant relationship between career growth with inspectors' job satisfaction. The coefficient beta for the independent variable career growth is 0.071 and the significant value is 0.000 which mean that $\mathrm{p}$-value is less than 0.05 . So there is a statistically significant relationship between the working condition and job satisfaction. This result supported the hypothesis 4 and is accepted.

The researcher believes that the level of career prospects among the inspectors is high due to their satisfaction with work in the inspection profession. This finding is consistent with the researcher's (Abele, Spurk and Volmer, 2011; Seibert and Kraimer, 2001).

Table.7 Summarised Result 


\begin{tabular}{|l|l|}
\multicolumn{1}{c|}{ Hypotheses } & Results \\
$\begin{array}{l}\text { H1: There is a statistically significant relationship between the nature of the Accept } \\
\text { job the inspectors and job satisfaction. }\end{array}$ & \\
\hline $\begin{array}{l}\text { H2: There is a statistically significant relationship between working } \\
\text { condition with the inspectors and job satisfaction. }\end{array}$ & Accept \\
\hline $\begin{array}{l}\text { H3: There is a statistically significant relationship between } \\
\text { motivation with the inspectors and job satisfaction }\end{array}$ & \\
\hline $\begin{array}{l}\text { H4: There is a statistically significant relationship between career growth } \\
\text { with inspectors' job satisfaction. }\end{array}$ & Accept \\
\hline
\end{tabular}

\section{Conclusion}

The ministry of manpower makes a great effort in caring for its employees and the factors encourage its employees to increase efficiency and job satisfaction. In general, employees whose job satisfaction increases, there will be a positive effect on performance and efficiency. In general, inspectors of the ministry of manpower are happy to work in the existing environment and they are free to carry out their tasks.

Job satisfaction among employees is a goal sort of thing that all decision-makers in all institutions look into. Based on the findings the following suggestions were made: The inspectors in the ministry of manpower are covered by comprehensive insurance for the risk of their jobs. Ministry of manpower inspectors are satisfied with the work conditions and expressed that all facilities are available by the Ministry of Manpower. It is recommended that increasing attention to the needs of working conditions for the inspectors, including rental cars and appropriate clothing for the visited sites. Conditions for entering site require special quality clothing, will enhance the job satisfaction of the inspectors.

Inspectors of the ministry of manpower are not satisfied with the motivation provided by the ministry of manpower, and it was observed that the inspection allowance provided is low compared to the workload provided by the inspectors and also compared to the inspection bonuses with other ministries of the same speciality. Therefore, it is necessary to give overtime to the inspectors after the official working hours as they work long hours. It is confirmed that the ministry gives incentive to the non-material inspectors, which contributes to encouraging enhanced competence and satisfaction among the inspectors.

Ministry of manpower inspectors are satisfied with the professional career growth and it is also confirmed that the ministry provides free scholarships, training courses inside and outside the country to ensure the inspectors' satisfaction.

\section{References}

1. Abele, A. E., Spurk, D., \& Volmer, J. (2011). The construct of career success: Measurement issues and an empirical example. Zeitschrift für Arbeitsmarktforschung, 43(3), 195-206.

2. Alegre, I., Machuca, M. and Mirabent, J. B. (2016). Antecedents of employee job satisfaction: Do they matter? Journal of Business Research, 69(4), 1390-1395.

3. Al-Hinai, Z. A. (2013). Factors influencing academic staff job satisfaction of higher education in the Sultanate of Oman, Doctoral dissertation, The British University in Dubai.

4. Al Shuhoomi, Y. M. S., \& Khan, S. (2019). The Impact of Demographic Factors and Big Five Factor of Personality on Job Satisfaction, International Journal of Innovative Science and Research Technology, 4(12), 960-967.

5. Al-Mahdy, Y. F., Al-Harthi, A. S., \& Salah El-Din, N. S. (2016). Perceptions of school principals's servant leadership and their teachers' job satisfaction in Oman. Leadership and Policy in Schools, 15(4), 543566.

6. Arafa, M. A., Nazel, M. W. A., Ibrahim, N. K., \& Attia, A. (2003). Predictors of psychological well-being of nurses in Alexandria, Egypt. International journal of nursing practice, 9(5), 313-320. 
7. Arnold, H. J., \& Feldman, D. C. (1981). Social desirability response bias in self-report choice situations. Academy of Management Journal, 24(2), 377-385.

8. Azeem, S. M. (2010). Job satisfaction and organisational commitment among employees in the Sultanate of Oman. Psychology, 1(04), 295.

9. Badawi, S., Reyad, S. M. R., Al-Hashimi, M., Al-Sartawi, A., and Al-Hashim Hamdan, A. (2019). The Role of Job Enrichment on Employees' Innovation in Services Sector: Telecommunication Companies' In Egypt. In International Conference on Innovation and Entrepreneurship (pp. 104-XXIV). Academic Conferences International Limited.

10. Baidoun, N. (2018). The Relationship Between Demographic Features, Career Satisfaction, and Organisational Commitment: Evidence from the Kuwaiti Banking Sector (Doctoral dissertation, University of Portsmouth)

11. Berelson, B., \& Steiner, G. A. (1964). Human behaviour: An inventory of scientific findings.

12. Betts, B. S. H. (2020). The Importance of Human Resource Management in the Hotel industry in Sierra Leone. American Scientific Research Journal for Engineering, Technology, and Sciences (ASRJETS), 64(1), 96-108.

13. Billingsley, B., Bettini, E., Mathews, H. M., \& McLeskey, J. (2020). Improving working conditions to support special educators' effectiveness: A call for leadership. Teacher Education and Special Education, 43(1), 7-27.

14. Brett, J. F., Uhl-Bien, M., Huang, L., \& Carsten, M. (2016). Goal orientation and employee resistance at work: Implications for manager emotional exhaustion with the employee. Journal of Occupational and Organizational Psychology, 89(3), 611-633.

15. Clark, A., Georgellis, Y., \& Sanfey, P. (1998). Job satisfaction, wage changes and quits: Evidence from Germany. Research in Labour Economics, 17.

16. Coomber, B. and Barriball, K. L. (2007). Impact of job satisfaction components on intent to leave and turnover for hospital-based nurses: a review of the research literature. International Journal of Nursing Studies, 44(2), 297-314.

17. Davis, K., \& Newstrom, J. W. (1981). Human behaviour at work: Organisational behaviour. New York: McGraw-Hill.

18. Drago, R., Estrin, S., \& Wooden, M. (1993). Pay for Perfor Mance Incentives and Work Attitudes. Australian Journal of Management, 17(2), 217-231.

19. Ekundayo, O. A., \& Ajanaku, E. A. (2018). The Impact of Motivation on Employee Performance in Selected Insurance Companies in Nigeria. International Journal of African Development, 5(1), 31-42.

20. Fieldman, C. D. and Arnold, H. J. (1983). Managing Individual and Group Behavior in Organization. NY: Hill Book.

21. Florence, O. (2014). Motivation And Worker's Performance (A Case Study Of Noma Children Hospital, Sokoto).UDUS Open Educational Resources, Project report submitted to Department of .Public Administration, Faculty of Management Science, Danfodiyo University

22. Greenhaus, J. H., Parasuraman, S., \& Wormley, W. M. (1990). Effects Of Race On Organisational Experience, Job Performance Evaluations, And Career Outcomes. Academy of Management Journal, 33(1).

23. Hans, A., Mubeen, S. A., \& Ghabshi, A. (2013). The SIJ Transactions on Industrial, Financial \& Business Management, 1(2), 93-100.

24. Harter, J. K., Schmidt, F. L., \& Hayes, T. L. (2002). Business-unit-level relationship between employee satisfaction, employee engagement, and business outcomes: A meta-analysis. Journal of Applied Psychology, 87(2), 268-279. http://doi.org/10.1037/0021-9010.87.2.268

25. Hofmans, J., Dries, N., \& Pepermans, R. (2008). The Career Satisfaction Scale: Response bias among men and women. Journal of vocational behaviour, 73(3), 397-403.

26. ILO (2008). Labour Inspection Structure and Organization - Information Resources, Oman. Available at https://www.ilo.org/labadmin/info/WCMS_150276/lang--en/index.htm

27. ILO (2011). Labour Administration and Labour Inspection - Report V. International Labour Conference, 100 th Session, International Labour Office, Geneva, 1-112.

28. Locke, E.A. (1970). Job satisfaction and job performance: A theoretical analysis. Organizational behaviour and human performance, 5(5), 484-500.

29. Maslow, A. H., Stephens, D. C., \& Heil, G. (1998). Maslow on management. New York: John Wiley.

30. McClelland, D. C. (1965). Toward a theory of motive acquisition. American psychologist, 20(5), 321.

31. Mesch, D. J. (2010). Management of Human Resources in 2020: The Outlook for Nonprofit Organizations. Public Administration Review, 70(S1), S173. 
32. Nchorbuno, D. A. (2011). The Role of Motivation on Employee Performance in the Public Sector: A Case Study of the University for Development Studies-Wa Campus (Doctoral dissertation).

33. Newstrom, J., and Davis, K. (1997). Organizational Behaviour: Human Behaviour at work, McGraw Hill Series in Management, McGraw Hill College.

34. Pauceanu, A. M., Hisam, M. W., \& Sanyal, S. (2016). Variables affecting employee SatisfactionEvidence from sultanate of Oman. International journal of applied business and economic research, 14(1), 499-510.

35. Reeve, J. (2014). Understanding motivation and emotion. John Wiley \& Sons.

36. Saragih, R., Luturlean, B.S. and Hadiyanto, F. (2020). Employee Job Satisfaction In Mediating The Relationship Between Work Motivation And Affective Commitment In Roof Tile Industry. Jurnal Bisnis dan Manajemen, 21(1), 16-26.

37. Sendagire, I., Schreuder, I., Mubiru, M., van der Loeff, M. S., Cobelens, F., \& Konde-Lule, J. (2010). Low HIV testing rates among tuberculosis patients in Kampala, Uganda. BMC Public Health, 10(1), 177.

38. Seibert, S. E. and Kraimer, M. L. (2001). The five-factor model of personality and career success. Journal of Vocational Behavior, 58(1), 1-21.

39. Short, J. L., Toffel, M. W., \& Hugill, A. (2019). Improving Working Conditions in Global Supply Chains: The Role of Institutional Environments and Monitoring Program Design. Harvard Business School Technology \& Operations Mgt. Unit Working Paper, 17-001.

40 . Small, G. J. (1971). Herzberg-Teller vibronic coupling and the Duschinsky effect. The Journal of Chemical Physics, 54(8), 3300-3306.

41. Troesch, L. M., \& Bauer, C. E. (2017). Second career teachers: Job satisfaction, job stress, and the role of self-efficacy. Teaching and Teacher Education, 67, 389-398.

42. Valaei, N., \& Nikhashemi, S. R. (2017). Generation Y consumers' buying behaviour in the fashion apparel industry: a moderation analysis. Journal of Fashion Marketing and Management: An International Journal, 21(4), 523-543.

43. Wasson, R. G., Hofmann, A., \& Ruck, C. A. (2008). The road to Eleusis: Unveiling the secret of the mysteries. North Atlantic Books.

Copyright: (C) 2020 by the authors. Licensee Global Scientific Publications, Oman.

This work is licensed under a Creative Commons Attribution-ShareAlike 4.0 International License.

This is an open-access journal and the articles published in this journal are distributed under the terms of CC-BY-SA. 